\title{
The Postmodern Spirit and the Status of God
}

\author{
by David H. Nikkel
}

[This article originally appeared in Sophia: A Journal for Philosophical Theology and CrossCultural Philosophy of Religion, 33, November 1994.] 
The Postmodern Spirit and the Status of God

In this essay, I propose to consider the status of the concept of God in light of the postmodern spirit. After characterizing the nature of this postmodern spirit, I will identify three options regarding the idea of God, arguing for the superiority of one of these.

\section{The Postmodern Spirit}

In my article, "Discerning the Spirits of Modernity and Postmodernity", I have claimed that the "controlling picture" or basic assumption of postmodernity is that a person is always standing in the world, with at least "one foot in" one's body, temporality, language, society, culture, history, tradition, etc. This contrasts with modernity's controlling assumption that the individual can leave behind all limitations of one's body and perceptual equipment, temporality, language, and culture and reach an absolutely privileged position where one can "see" everything, including oneself, with total clarity.

Some ramifications of this postmodern spirit are:

1) Epistemologically someone knowing or perceiving something is the only starting point. Neither mind/subject or body/object is an absolute or privileged starting point. The attempt to reach a subject in itself (in total distinctness from any object known) or an object in itself (in total distinctioness from any subject 
knowing it) is misguided in principle. There is no direct or immediate knowing of a subject in itself nor or an object in itself. And there is no pure or absolute subject to be abstracted out of the world and society in which one is embodied.

2) Our knowing plays a constitutive part in what we know. Knowing or perceiving, which involves desiring and acting, play a significant role in creating the world we experience. As Cezanne's out of focus paintings suggest (these can be regarded as artistic harbingers of a postmodern age), reality is fuzzy or indefinite apart from our participation which brings it into definition (Poteat: 59).

3) Absolute schemas are suspect, whether binary oppositions such as subject/object, mind/body, sense/reason, or human/natural worlds or postulations of the essence of being, human nature, history, religion, or a text. Such absolutistic or rigid schemes of categorization miss the richness, complexity, interrelatedness, and contextuality of life, especially in its temporal and changing character and in its prereflective and tacit dimensions.

For our purposes, we can note three important entailments of the postmodern spirit: A) Human knowledge is always mediated, constructed, or contextual (at least in part). B) Creatures are interconnected with one another and with the world. Persons are not simply or absolutely distinct from one another and the environment; we are also a part of one another and the environment. Where self ends and other begins is not clear-cut but relative to context. C) The body is crucial in all our 
knowing and relating. Here body is understood not as something split from mind nor simply physical, but as correlative with consciousness. A person is rather a mindbodily continuum. "Mind", as being aware of and attempting to make sense of things, and "body", as that with which we have and relate to a world are not simply distinguishable but are radically interrelated, and both come into play at some level in all our acts.

\section{The Three Types}

I find in contemporary theology and philosophy of religion three types of response sympathetic to the postmodern spirit regarding the viability of the concept of God. In brief these responses are: 1) minimalist conceptions of God; 2) denial of the concept of God, the "death of God"; 3) fairly traditional conceptions of God.

Given the wariness of the postmodern spirit about grand claims to knowledge, it is not surprising that some philosophers of religion and theologians are offering minimalist conceptions of "God." One such thinker, a senior statesman on the theological scene, Gordon Kaufman, has moved from more traditional understandings of God. In his latest work, In Face of Mystery, Kaufman identifies God with "serendipitous creativity" (especially, 264-80). Kaufman opts against attributing to God personality, consciousness in any sense, intentionality, or agency $(268-72,329)$. This is in contrast to earlier work that characterizes divine creativity in terms of an overarching "act" 
(Kaufman, 1968:50-56). Kaufman even expresses an unwillingness to assign any actual transcendence to God, finding it sufficient to identify God with, or as wholly within, the cosmic process (1993: 271-72)1. There are, however, some countervailing tendencies where some transcendence seems to come in through the back door, as when Kaufman speaks of God as "ground[ing]" (296), "underlying" (330), "behind" (297, 418), "unifying" (418), "expressing itself" $(296,417)$, or "working" $(297,330,339,415)$ in and through all processes, all reality. In this minimalist project Kaufman hopes to reconstruct the concept of God so that both theists and nontheists who find the universe conducive to life and its fulfillment can find common ground as to an ultimate concept. In a similar vein to Kaufman, Sallie McFague declares in Models of God that all Christianity claims "with any assurance" about ultimate reality is that it is supportive of life and its fulfillment, and she parenthetically adds--claiming more than Kaufman--that this power is "personal" (x). Anything beyond that reveals something about how human beings should or do understand themselves, their society, and their world, but does not reveal anything more about God.

I should note that such minimalist conceptions of God are not new with the current scene. For example, in the 1940's Henry Nelson Wiemann developed a process perspective that identified God with the growth of value in the universe. Similarly, John Dewey

1officially transcendence is either unknowable (the ultimate mystery [415]) or merely formal ("the (imagined) ultimate point of reference" [327]). 
identified God as the process of human beings interacting with the larger environment, ever creating new values. In "Discerning the Spirits of Modernity and Postmodernity," I have claimed that the shift from a modern to a postmodern age has been a gradual and ongoing one that began in the nineteenth century. If this is the case, it is not surprising that minimalist ideas of God are not brand new. Interestingly, what is perhaps new is that such ideas are now being advanced by thinkers in their capacities as mainline Christian theologians rather than by thinkers, albeit influenced by the Christian tradition, writing solely or mainly as philosophers of religion.

The above kinds of minimalist conceptions of God are attractive in avoiding both modern absolutism and relativism (the latter following from the failure to realize absolute knowledge and presence). They also are conducive to the postmodern concern to respect "otherness", in granting that other religious--and secular--traditions are compatible with the most basic Christian or metaphysical claims. These conceptions do retain something of the basic western notion of God; though, the crucial question is whether they retain enough of that meaning to be judged a development of rather than an alternative to the concept of God. Minimalists can point to the negative theological tradition and to a traditional idea that we can only know God in relation to us, but not in God's self. On the other hand, thinkers of the via negativa, in affirming the divine infinity, unity, and transcendence have claimed much more than the minimalists. 
Parenthetically, I do wonder if Sallie McFague would spend so much time developing symbols for God if she truly believed these told us nothing about the nature of ultimate reality but were only socially useful.

More traditional conceptions of God provide an explanation of the universe--regarding it as caused by a conscious, intentional, and integrated reality--while minimalist conceptions attempt to be only or mainly descriptive of the universe. For those who feel the universe is amenable to an ultimate explanation, minimalist ideas will obviously be inadequate.

I believe it is an uncontroversial claim that the large majority of contemporary theistic believers would find minimalistic ideas not to correspond sufficiently to what they mean by "God." However, the question of whether most future believers in the Christian and western traditions will understand "God" in terms of "minimalist" conceptions is still to be decided --and minimalist thinkers are arguing that in light of the postmodern spirit this is the direction in which the concept of "God" should be modified. Later I will argue my position that the concept of God does not need to be changed so radically to be viable for an emergent postmodern age.

I have indicated that minimalist ideas respect otherness in granting the truthfulness of basic claims of other religions and world views. However, the compatible truthfulness that is granted is of a generalized and demythologized sort. More particular and traditional claims of other religions are not acknowledged by the 
least common denominator approach of minimalism--even as most of the particular or traditional claims of Christianity are jettisoned. Differences among other religions are not sufficiently respected, even as Christianity's own particular otherness--how it is different from other religions--is not sufficiently respected. My sense is that genuine dialogue is short-circuited in a leap to a least common denominator.

The second response holds that the absence of any absolute possession of truth or of the self by humans entails the absence of any absolute reality. On the plane of logic, this "death of God" or radical position is in error. Granting the contextual relativity of all human existence and meaning does not rule out the possibility of an absolute being or reality. The absence of any absolute human connection to the Absolute does follow from a consistent upholding of the contextual and mediated quality of all human knowing; but whether an absolute reality exists and can be known--relatively, of course--is not all settled by the acknowledgment of radical human contextuality.

In fairness to radical thinkers, they do not explicitly claim logical entailment of the denial of absolute human meaning with the death of God. Rather the death of God is more an outgrowth of the spirit of this age. Assumed here is that God is basically a projection of human desires and values. Then as notions of human absoluteness gradually fade, so eventually fades away the affirmation of God.

Radical postmodern thinkers include Mark $\mathrm{C}$. Taylor in the 
Protestant tradition and D.G. Leahy in the Catholic tradition. Reacting radically against modernity's picture of absolute transcendence, such thinkers take postmodern insight to entail the total immanence of a person in one's experiences: we are immersed in our perceptions, our words, our interpretations, our representations, our constructions of reality--and there is nothing more, at least that is knowable.

While "God" is dead, these radical thinkers do not necessarily eschew some notion of divinity. Even as the person is wholly immanent in one's body and experiences, so divinity may be wholly immanent with respect to the world--even more so than in any traditional pantheism. Taylor writes of "the ever-neverchanging-same [that] is the eternally recurring play of the divine milieu in which all things [emphasis his] arise and pass away" (1984: 112-20, 183). Leahy exalts, "As never before the divine flows absolutely. In this flow every notion of self is completely dissolved" (786). Such immanentalism which affirms the interconnected totality of all that has or will transpire is in tension with an attitude of ironic relativism toward the various interpretations or constructions of reality in which individuals are immanent (an attitude that tends toward nihilism). It appears that radical immanentalism can avoid the standing nowhere of nihilism only by trying to stand everywhere. In works after Erring, by the way, Mark C. Taylor backs off from a divine immanentalism, sensing the totalizing tendencies of its backdoor retrieval of immediacy and full presence (e.g., 1991: 1-34). 
We come now to the third type, those acknowledging the postmodern spirit, but retaining a fairly traditional idea of God2 :

In Varieties of Postmodern Theoloav, David Griffin recommends process theology's conception of God as especially appropriate to the postmodern spirit. It is certainly the case that the temporality and the interconnectedness, correlativity, and sociality of life that the postmodern spirit affirms find in process thought counterparts in the nature of God: God has a genuinely temporal dimension in relating to the world and God is affected by the creatures who are in some sense a part of God. On the other hand, in two ways process theology seems more modern than postermodern: 1) Its theories that all reality consists of "occasions of experience" and that all causation, including divine agency with respect to the world, consists of the prehension of past occasions of experience by present ones smack of modern

2 I will here mention those known as postliberal thinkers. Though coming from the conservative side, they share with the radical postmodernists an emphasis on human immanence in particular "cultural-linguistic" frameworks (Lindbeck). However, after affirming the postmodern spirit and both the selfauthenticating and apparently somewhat relativizing contextuality of Christianity and other world views, postliberals go on to claim for Christianity alone an absolute connection with God, an exclusive revelation from an extra cultural-linguistic reality. Thus a traditional, particularist vision of God emphasizing divine freedom and transcendence is affirmed, where God chooses to reveal God's self in a particular tradition in lieu of a more universal immanence (while human freedom and transcendence are downplayed or denied). Often postliberals explicitly eschew the tasks of philosophy of religion, natural theology, or apologetic theology. However, in appealing to postmodern logic, postliberals are implicitly offering an epistemological defense of their right to hold a very traditional idea of God, though, as I have argued, not consistently or effectively. 
idealist reductionism. 2) Despite its emphasis on sociality, its theory of causality is ironically individualistic, indeed atomistic. God affects only individual occasions of experience, through their prehension of God as an attractive object (albeit God does attempt to influence the myriad creatures to make decisions conducive to an integrated world).

Various thinkers have offered conceptions of God that are traditional in affirming divine creativity, supreme power, omniscience and transcendence in the sense of some distinctness with respect to the world, while like process thought also upholding divine temporality and responsiveness/reciprocality with respect to the world. 3 I would want to push this tendency by developing and promoting an explicit and full-fledged panentheistic understanding of God, which I will argue is very apropos vis-a-vis the postmodern spirit.

\section{The Inevitability of Metaphysics}

Preliminary to that, however, there are some metaphysical and epistemological issues to consider. Some will presume that, given the limitations on human knowing recognized by the postmodern spirit, either the minimalist or radical perspective is credible, while more traditional conceptions of deity can no longer be plausibly defended. I will argue otherwise.

\footnotetext{
${ }^{3}$ E.g., Nicolai Berdyaev, Pierre Teilhard de Chardin, John MacQuarrie, Hans Jonas, Matthew Fox.
} 
To lead into these considerations, I will offer an observation relative to our preceding discussion. All three types share an emphasis on immanence in comparison to the relative emphasis on transcendence of classical theistic models. The radicals do away with all transcendence, the minimalists allow just a hint of it, while "traditionalists" affirm a substantial measure of transcendence. On one level, minimalists and radicals may evidence cognitive humility; however, to deny transcendence and make the ultimate more or less equivalent to the (processes of) the universe is in fact a definitive stand that claims much. While any transcendent aspect of the ultimate may be more difficult to know compared to an immanent aspect more immediately connected to observation of the universe, to more or less deny the reality of a transcendent dimension is hardly humble. A more "humble" position would be to say we can neither affirm nor deny anything regarding divine transcendence; nor can we say much, if anything, about immanent ultimacy or deity nor about the purposes and integrity of the universe, in as much as we are ignorant of the relationship, if any, of divine immanence to transcendence. The above hints that the eschewal of metaphysics by radicals and some other thinkers is not humble--nor successful. Far from being impossible since kant's critique, metaphysics, while problematic, is inevitable. Every position or worldview involves beliefs and assumptions about the ultimate nature of reality and the nature of ultimate reality. To say that metaphysics is impossible itself claims something significant about the nature of 
our universe--namely that the universe is so constituted that the ultimate nature of things is unknowable.

Deconstructionists are rather specific in their "knowing" claims about the unknowability of things, claims that are not merely epistemological, but metaphysical; e.g. 1) no cognitive closure is possible; 2) there is no "reality", all is interpretation, representation. 4

The postmodern perspective holds that meaning is contextual, temporal, and to a great extent, tacit; a corollary of this in that when we attempt to represent, reflect upon, or make explicit an experience, there is no absolute "translation"; rather there is always some distancing or gap between referrent and signifier. Derrida refers to the phenomena that representations never absolutely capture "reality" by the rubric differance. In Derrida's thought differance seems (almost?) reified and, in any case, functions like an overarching metaphysical category that includes the judgment that meaning is very unstable.

Some who are more traditional, like Marion and Kaspar, try to sidestep metaphysics by speaking of God in terms of "love" and "freedom", rather than of "being". Whatever the value of this move may be, they are still maintaining an infinite and ultimate reality, necessary and absolute in some sense, that is the creator

$4_{F o r}$ the postmodern spirit, in light of the inexhaustibility and temporality of life and creaturely fallibility, there is no absolute closure. Yet most creatures achieve adequate cognitive closure and determinacy most of the time, according to a moderate postmodern perspective. 
of the world. Clearly there are definite metaphysical commitments here, too, even if some of the terminology is more "biblical" than "philosophical". What is impossible and wrongheaded is the enlightenment absolutism that assumed we can establish neutral, universal metaphysical beliefs that all "reasonable" people will subscribe to. Given the plurality of metaphysical perspectives, radical postmodernists, "postliberals", and some others endorse incommensurability. The notion of the ultimate incommensurability of world views itself involves a metaphysical commitment. (In) commensurability must be argued. (It is not within the scope of this project to argue directly on this issue.) To conclude this section, those who take atheistic, agnostic, or minimalist positions regarding (ultimate) reality should not have their (often unclaimed) metaphysical commitments automatically granted a privileged status.

IV. The (Un) Knowability of God

Having argued for the inevitability of metaphysical commitments, I will now consider the issue of the (un)knowability of other beings, which may have some relevance to the question of the (un) knowability of God. One aspect of radical postmodernism is its positing of our immersion in our constructions, interpretations, representations of reality. In tension with this immanentalism with respect to meaning is radical postmodernism's emphasis on the indeterminancy, shiftiness, self-deconstructing or self-oppositional nature of meaning: the "otherness", even if 
unacknowledged, of all meaning, including the otherness within the self. (Perhaps what ties together these two tensive aspects is a lack of transcendence or freedom with respect to meaning: we are immersed in a constantly shifting interplay of the presence and absence of meaning.) If deconstructionism played only its immanentalist card, radical postmodernism would parallel the solipsistic tendencies of modernity. If the referentiality of perception and language becomes intractably problematic or impossible, then the very possibility of knowledge about entities somewhat external to us--not only God, but other human beings (and even reflective self-knowledge)--becomes doubtful or impossible. 5 Deconstructionism's "otherness" card itself involves a tension. On the one hand, one could affirm the possibility of knowing, experiencing, or communing with the "other". This involves alterity becoming less other, becoming a part of oneself to some extent. On the other hand, one could emphasize the irreducible alterity or "strangeness" of the other. This has been the tendency of Mark C. Taylor (1987). Combining immanentalism with irreducible alterity might lead to a solipsistic conclusion. However, in practice, radical postmodernism has not denied our knowing other human beings. Rather, it has held only that much about other persons must remain "other" to us. While agreeing with the substance of this conclusion, I demur from the tone of

5 John Caputo has recently argued that Derrida's emphasis on aterity gainsays interpretations of Derrida that entail our entrapment in language (or better, all our constructions of meaning). While I have noted the tension here, I believe this tension is clearly present in the work of Derrida and other deconstructionists (e.g., Derrida, 298). 
"strangeness", and note that there is much we can know about other human beings. If the postmodern insight that perception, symbolism, and language are never purely, transparently, or simply representational does not preclude knowledge of other beings, then one cannot preclude knowledge of God based solely on that insight. Instead, one must make a specific argument why God is uniquely unknowable, why the one sometimes called the wholly other must remain the (perhaps nonexistent) epistemologically wholly other. God, of course, has been understood traditionally as an ontologically and epistemologically exceptional case--without denying that some knowledge of God is possible. Some thinkers have made a sharp distinction between God in relation to us (somewhat knowable) versus God in God's own self (unknowable). John Hick with his Kantian contrast between the phenomenal and noumenal with respect to God (42ff, 83-87, 71-92) and Robert Neville with his distinction between God as expressed in creation and God as "utterly indeterminate" (8) are contemporary examples. Martin Heidegger has probably been the most influential contemporary thinker to use such a distinction, in this case that between Being and particular beings. Heidegger's distinction entails a "differentiating process which simultaneously connects them and holds them apart" (Godzieba). Traditional theology, on Heidegger's critique, has identified God with Being, while understanding Being as analogous to beings; thus God has been (incorrectly) put within the grip of the differentiating process (70-72). If God is instead understood as prior to the 
differentiating process, then our only hope for knowing God is a glancing revelation. Regarding such revelation as impossible, many interpret the upshot of Heidegger's critique to be the impossibility of knowing God (Godzieba).

I am not ready to accept a too sharp distinction between a transcendent (God in God's self) and an immanent (God for us) aspect of the divine. Such dualism is more in keeping with the modern than the postmodern spirit, seemingly an extension of subject-object dualism. The controlling picture of modernity created the problem of knowing other minds by its privileging of self-reflexive subjectivity. However, in normal experience, from infancy on, we learn about self and others correlatively through our and their embodiment. (There is no reason to privilege our own subjectivity and intentionality, while doubting that of others.)

My thesis is that we likewise know God through our--and God's--embodiment in the world. If we grant the dualism between God in relation to world and in God's own self, we have already lost the epistemological ball game to the agnostic and atheistic interpreters of Heidegger. For if God in relation to the world-divine immanence--cannot disclose anything about God's self or nature, that is, at least something of the value and purpose of creation for God, then indeed we have no right to postulate anything transcending the processes of the cosmos. But if we allow the possibility of some continuity or connection between God in relation to world and God's self and intentionality, knowledge 
about the world (divine immanence) may yield some knowledge of the divine self or nature as more than world. Granted there is a distinction between the subjectivity-objectivity correlation in the world on the one hand and that which is prior to creaturely subjectivity-objectivity on the other. Yet I see no justification to a priori preclude knowing something about the initiator of the "differentiating process of being" by means of those processes of being. Panentheism, in particular (which shortly will be more fully expounded), offers a model where God is partially differentiated or distinguished from creation, but is not subject to the differentiating process in the way the creatures are, for God initiates, controls, and encompasses that process; thus, God is both immanent in and transcendent of that process. Because God is prior to that process, it can be part of God and God can be part of it.

Some radical postmodernists, such as charles winquist, have made a more particular disclaimer of the possibility of knowledge of God. They have maintained that theological claims are wholly within a culture and language, and so cannot hope to refer to any transcendent reality. This seems to me a rather weak argument. Language and culture are continually changing, yet we are quite capable of partially transcending a given version of these in understanding new versions. Moreover, I submit we can have some understanding of other cultures and religions (albeit we do not understand these exactly as natives do). Furthermore, I submit that we can have some understanding of meaning for animals who are 
not part of any human language or culture (albeit our culture has some effect on our interpretation of these meanings). If we can partially transcend our cultural-linguistic frameworks to know something of these various others, there is no a priori reason to deny we may do so with respect to ultimate reality.

I have attempted to refute epistemological and metaphysical arguments and question-begging assumptions against the possibility of metaphysics generally and, in particular, a more than minimalist theistic metaphysics. Hopefully having succeeded in clearing the decks for those who would develop modified traditionalist understandings of God, here is my attempt.

\section{A Panentheistic concept}

Panentheism literally means "all [is] in God". The world and its creatures are part of God. There is an intimate connection, an immediacy of presence, of God to all that exists that surpasses the closeness of any creature to any other creature and even to itself. God knows all that exists without externality, mediation, or loss (though God's knowledge and valuation are more than the creaturely experiences that are wholly included in the divine experience). God also empowers all that exists without externality or mediation (save for the "externality" of some genuine indeterminacy and freedom of choice and action which God empowers in the creaturely realm).

God directly knows all that happens, all the joys and sorrows, the goods and ills of the world, and the divine beatitude 
is therefore affected by what happens. God directly empowers what happens in the world, including some indeterminate freedom; therefore God is both active and passive or receptive in relation to creation. The metaphor of the world as God's body is an appropriate one for panentheism, for a creature has a (comparatively) direct awareness of much of what happens to its body and a (comparatively) direct control of much of the actions of its body. I grant it is controversial as to whether an immediacy or directness of divine power can be construed in such a way as to safeguard genuine creaturely indeterminate freedom. Elsewhere I have argued this compatibility (forthcoming; 1993), though such an argument is not within the purview of this project. Even as panentheism resists the tendencies of traditional theism to simply distinguish God from the creation, so it resists the tendency of pantheism to reduce God to the world--to its creatures, its structure, or the universe as a whole. In the postmodern vision of the human being, the person is neither simply nor absolutely distinguished from the body, the environment, and other creatures; neither is the person simply equated with, or undifferentially part of, the body, the environment, or other creatures. In its refusal to simply distinguish God from, or simply equate God with, the world and in its affirmation of God's embodiment in the world, panentheism offers a vision of God compatible with the postmodern vision of human beings and, I believe, compatible with the nature of reality and ultimate 
reality. 6

While I am not alone among contemporary thinkers in advancing a panentheistic view of God, my approach differs from two other types: 1) for some, such as sallie McFague, their development of panentheism is, relatively speaking, on a metaphorical level, while my development of it is relatively more conceptual; 2) I offer a fuller version of panentheism than does process thought, in which God is panentheistic only as passive, not as active.7

VI. A Postmodern Epistemology: The Embodiment of God

I have argued against the a priori, carte blanche unknowability of God (as well as offered a panentheistic conception of God that I believe will prove to be epistemologically defensible). There are, however, certain traditional sources for knowledge of God that must be discounted by the postmodern spirit. For if we apply the denial of absolute, direct, unmediated knowledge to our knowing of God, then we must deny the validity of the following: 1) revelation in the sense of a supernatural, self-authenticating action of or communication from God, 2) mystical experience as a direct awareness of the very consciousness or essence of God.

6Interestingly, Kaufman decries "the idea of God as essentially an autonomous ego--utterly distinct from and independent of all other agents" (332), yet does not indicate why a panentheistic or other nonminimalist organic conception of God cannot adequately address this and other shortcomings of the traditional model.

7 I have argued this point at some length in a paper entitled, "A Full-Fledged Panentheism: An Idea Whose Time Has Come?" (1993), and in my forthcoming book, Panentheism in Hartshorne and Tillich. 
The modern spirit has led many to deny tangible supernatural activity in the physical world. The notion of some direct divine presence or communication to human interiority, though, has been somewhat less suspect. However, if the logic of the postmodern spirit is played out, this notion, too, must fall. Some thinkers in the tradition of Barthian neo-orthodoxy, including the postliberals, have attempted to distance themselves from supernaturalism, while still maintaining--if not explaining--the absolute, self-authenticating character of divine revelatory activity. This too must fail according to the postmodern spirit. While mystical experience may have some validity as a mode of consciousness that attunes one to the truth of the interconnectedness of all reality, postmodernly it cannot be understood as directly induced by God nor as a tapping into the very mind or consciousness of God. By way of contrast, much influential modern theology, affected by Romanticism and/or idealism, has included some version of a direct or mystical awareness of God: Tillich's "mystical a priori", neo-Thomism's implicit awareness and love for God, and Whitehead's "initial aim".

If in the postmodern spirit we rule out any absolute or unmediated human connection with God, then I submit that how we know God should not differ in principle from how we know other realities. As I have indicated, for the postmodern spirit, knowing is bodily knowing. Here body is not discontinuous with mind. Some knowing is relatively reflective; other knowing is 
more pre-reflective. All our knowing, however, is through our and others' embodiment in the world. Therefore, as I suggested earlier, whatever knowledge we have of God will come from our and God's embodiment in the world.

Even as we know of the reality and intentions of others through the processes and actions of their bodies, so the world's processes and activities are interpreted as the body of God that gives us knowledge of the reality and intentions of God--including the intention that there be sentient, conscious, valuing life. The universe is regarded as a body supporting life, providing order--or a proper mix of regularity and chance, and creating beauty. Some of this knowledge will be relatively reflective, such as 1) the Big Bang and the evolution of stars, planets, and life; 2) the balance of atmospheric composition, pressure, and movement, of temperatures of ocean, land, and air, etc., that provide an environment conducive to the preservation of life. Some of this knowledge will be relatively pre-reflective, such as an intuition of God's purpose in viewing the beauty of a sunset or 
in the experience of pregnancy and birthing. 8 This paragraph has been meant to be suggestive rather than exhaustive as to how we might discern God as embodied in the world. One's sense of God and the world here must be cumulative and integrative or holistic. It is an interpretation of the whole of one's embodied existence. Clearly the universe contains many particular instances of evil. The theist will likely interpret this as an inevitable dimension of powerful, yet fragile, processes that assure the good of the whole. The theist then will have an overall evaluation of the world as good and purposeful, though taking into account the many negativities of existence.

${ }^{8}$ Clearly this model for knowing God has similarities to traditional teleological arguments for God's existence. Perhaps the main departure or innovation is the intimacy of the perceived connection between God and the world's processes with a panentheistic understanding of the world as God's body.

A similarity to traditional cosmological arguments can also be drawn. If "body" is split from "mind", that is, if the world is split from divine awareness and purpose, then the world is only physical and its existence is simply and absolutely contingent. This leaves the existence of an integrated world, of something rather than nothing, wholly unexplained. If instead God is understood as necessarily existent, the integration of the universe is explained as correlative with the integration of divine awareness and intentionality.

Obviously my model of knowing God's intentions through the actions of God's body focuses on general processes; it relates to "general" rather than "particular" providence. Someone might want to argue that particular events, such as the crossing of the Red Sea by the Israelites, are actions of God's body through which we discern God's intentions. Perhaps such a model could be reconciled to the postmodern spirit by claiming that particular revelations are never unambiguous or certain. While allowing that some events or persons or texts may be revelatory of God's nature. I nevertheless cannot accept them as special actions by God. Even if construed as not involving supernatural intervention, creaturely indeterminacy and freedom must be kept within very narrow bounds, if present at a11, to maintain that God is agential in, and responsible for, these events beyond God's general activity in and empowerment of every event. And then we are left with the question of why God is especially responsible for foreplanning and causing these particular, admittedly ambiguous events, but not all other particular events. 
We cannot legitimately doubt that we know persons' intentions through their bodily actions. While we may be wrong in our reading of particular actions and intentions, practically speaking we cannot generally doubt this kind of knowing--and certainly not the existence of other embodied persons--unless one creates a philosophical problem under the influence of the spirit of modernity or is emotionally disturbed.

Is our knowing through God's embodiment equally certain? Alvin Plantinga has labelled beliefs in the existence both of other minds and of God as "properly basic" (Plantinga).9 Clearly, many in secular society and in nontheistic religions doubt the existence of a God who is discernible in and through the world. Even as a confirmed theist, I would hardly claim that my knowing God's existence is as obvious or indubitable as my knowing the existence of other persons. Yet the embodiment of God in the world is a plausible metaphor, intuition, and inference.

If this is so, the question remains as to how much we can plausibly claim to know about the God embodied in the world. I have thus far suggested that we can discern God as creator and

9John V. Apczynski has recently made, I think, a convincing case that "proper basicality" must be understood as within a particular historical tradition of inquiry, in Plantinga's case, the Reformed tradition of Christianity. Yet I would want to ask about the models of knowing that historically have led to belief in God as properly basic in that tradition. One model has involved belief in absolute and self-authenticating supernatural revelation. Another model, controversial as an interpretation of Calvin and the Reformed tradition, posits a direct "awareness of divinity", albeit obscured by sin (Plantinga: 65). Of course, both models are suspect for the postmodern spirit. Another model involves discerning God's existence and intentions through observing the world, which I obviously accept as a viable option, even though not so properly basic as our knowledge of other persons. 
valuer of sentient life. But can this model of the world as God's body support knowledge of a God who is conscious, knowing all that has transpired to this point, immediately empowering the being of the world, and whose existence is necessary--or can it at best support a more minimalist conception? If one admits the discernibility of any intentionality or purposefulness in the world (beyond that possessed by the individual creatures), one is, I think, admitting that God is conscious or intentional--or not less than conscious or intentional (if one prefers this latter wording, I have no objection). However, if one balks at the discernibility of intentionality, I would submit that the existence of conscious, intentional beings in the universe is best explained by a conscious, intentional God of whose body these other beings are part--while such beings arising from a universe that is as a whole nonconscious and nonintentional is incongruous. If it is thus granted that a conscious, intentional God has played a causative role in this universe's existence, I judge it to be at least plausible that this God is both desirous and capable of knowing whatever happens in this universe.

What of the panentheistic intimacy of the world to God-including an immediate empowerment of the world? All three postmodern responses focus on the universe in framing ultimacy. Given this focus and given that our method, our heuristic model, for knowing God is postulating the universe as God's body, if we find evidence for a conscious, intentional, causative, knowing God, a great degree of immanence of the world with respect to God 
must be affirmed. But must there be an absence of externality, save for the indeterminate freedom of the creatures? Certainly in the human case, there is much about one's body that is outside one's awareness, intentionality, and control. However, in sensing the world as God's body, there is a sense of the ultimacy or holiness of the whole that is the embodied God. It is this sense of ultimacy that will not brook externality of God's power and knowledge with respect to God's body, the world. Yet we also sense that not all is as it ought to be in God's body. In or despite the immediacy of divine presence to the universe, God permits and empowers a significant amount of chance, spontaneity, indeterminate freedom in parts of God's body.10 Thus while divine presence, knowledge, and empowerment are immediate, divine intentionality is partly permissive and divine control is far from total land divine knowing does not foresee future creaturely decisions to the extent these are indeterminate).

Finally, the necessary existence of God is implicit in the sense of ultimacy and is correlative with panentheistic immediacy. Positively, only a God who possesses its own power of existence would be capable of immediate presence to all else that exists. Negatively, positing the externality of the world with respect to God implies a "God above God", to use a Tillichian phrase, who includes and empowers both this supposed God and the creatures, setting the conditions and structures for the interactions of these relatively external beings.

10 In itself this is only a partial explanation of the evil in the world. 


\section{Divine Absence and Presence}

A sense of the absence of God has figured in much modern and postmodern (a)theological discussion. I believe that the panentheistic formulation I have advanced can account for a certain sense of divine absence, while still allowing for the reality and presence of God.

Clearly my model--and many other models--postulate the absence of particular, distinguishable actions in which God is especially or uniquely agential. Informal surveys in my classrooms suggest that most people in the United states at some point in their lives have wished for some direct sign from God as to God's existence or as to a direction for one's life. The same surveys also indicate that most people do not believe they have received such a sign. Many have felt the absence of God in the sense of particular, distinguishable actions.

Due to the all-inclusive or all-encompassing nature of God, the immediacy of creation to God's awareness and power, on my panentheistic conception, no particular event, experience, or action in the world can be simply distinguished from God and the divine life. Thus, there is a sense in which God is both nothing ("no-thing") and every thing. God is not uniquely nor exhaustively identifiable with any particularities of this world, yet God immediately includes and identifies with all the particularities of the cosmos.

On my model, the including whole is immediately aware of the included parts. However, the converse does not hold. The 
creatures, the parts, have no immediate or mystical awareness of the divine consciousness, the transcendent aspect of deity, or the whole as more than the included universe. We have no immediate knowledge of God's immediate awareness and empowerment of us, of our unmediated presence to God. Probably this is precisely what we should expect with a panentheistic model. Because God is not a clearly distinct being or cause, because there is no resistance to our immediate presence to God, there is nothing particular of God's inclusion to distinguish (from what we experience of ourselves and of the universe); there is nothing particular thereof that is external to us or different from us to perceive. We are an immediate part of God, but God is not similarly an immediate part of us, even in attenuated form.

As I have suggested, whatever knowledge we have of God is mediated, even as is our knowledge of creaturely others (and many would hold, even our knowledge of our own bodies, emotions, etc.). In the case of other creatures, it is particular aspects of the world, particular embodiment(s) that enable knowledge. In the case of God, it is the whole universe as embodiment that enables knowledge. This involves mediation and interpretation of a different order than our knowledge of particular or fragmentary entities. It is a holistic or integrative interpretation that makes a judgment based on what knowledge one has of the whole universe. To be sure many particular experiences and elements inform such judgment (for example, I earlier mentioned somewhat particular processs conducive to life). However, none of these in 
themselves are taken as immediately, uniquely, or decisively revelatory of God. Rather they are part of a contextual interpretation of the nature of the universe and of the one who is embodied in the universe. If one does not allow the possibility of God acting or revealing God's self in exclusive, particular ways, then one must make a judgment as to the absence or presence of God based upon an overall judgment about the nature of our universe.

In this article I have argued that the nature of the universe is epistemologically consistent with the model of the world as the body of God, God being conceived in a fairly traditional manner, but with significant modifications to reflect a full-fledged panentheism. 


\section{References}

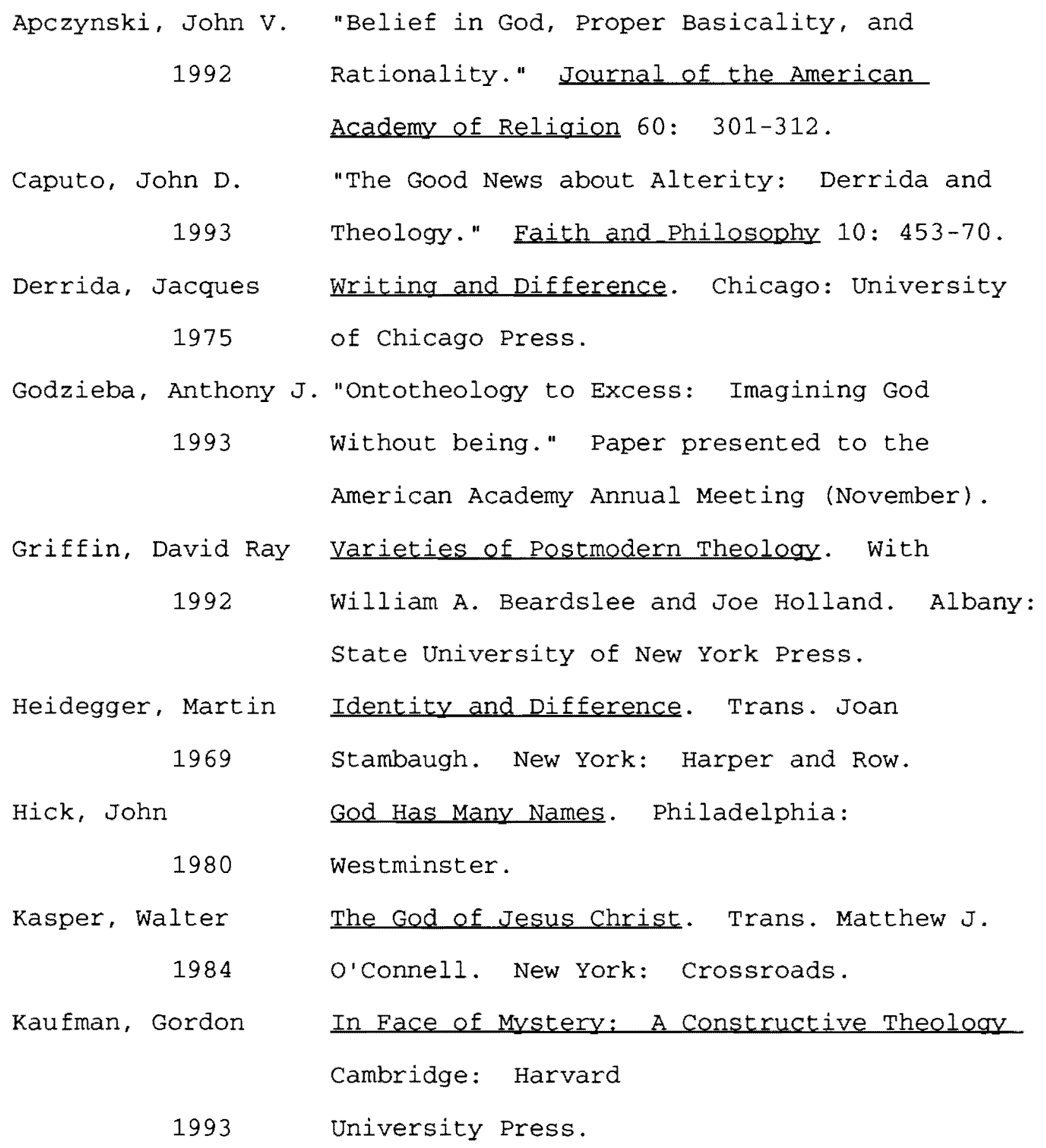


1968

Leahy, D.G.

Lindbeck, George

MCFague, Sallie

Marion, Jean-Luc

Neville, Robert C. 1988

Nikkel, David H. forthcoming 1994
Systematic Theology: A Historicist

Perspective. New York: Charles Scribner's Sons.

"To Create the Absolute Edge." with an

Introduction by Thomas J.J. Altizer. Journal

of the American Academy of Religion 57: 773789 .

The Nature of Doctrine: Religion and Theology in a Postliberal Age. Philadelphia:

Westminster Press.

Models of God: Theology for an Ecological. Nuclear Age. Philadelphia: Fortress Press. God without Being: Hors-Texte. Trans. Thomas A. Carlson, Chicago: University of Chicago Press.

"The Depths of God", Journal of the American Academy of Religion 56:1-22.

Panentheism in Hartshorne and Tillich: A

Creative Synthesis. New York: Peter Lang. "Discerning the Spirits of Modernity and Postmodernity." Journal of Religious Studies.

"A Full-Fledged Panentheism: An Idea Whose Time Has Come?" Paper presented to the Rocky Mountains--Great Plains Regional Meeting of the American Academy of Religion (April). 


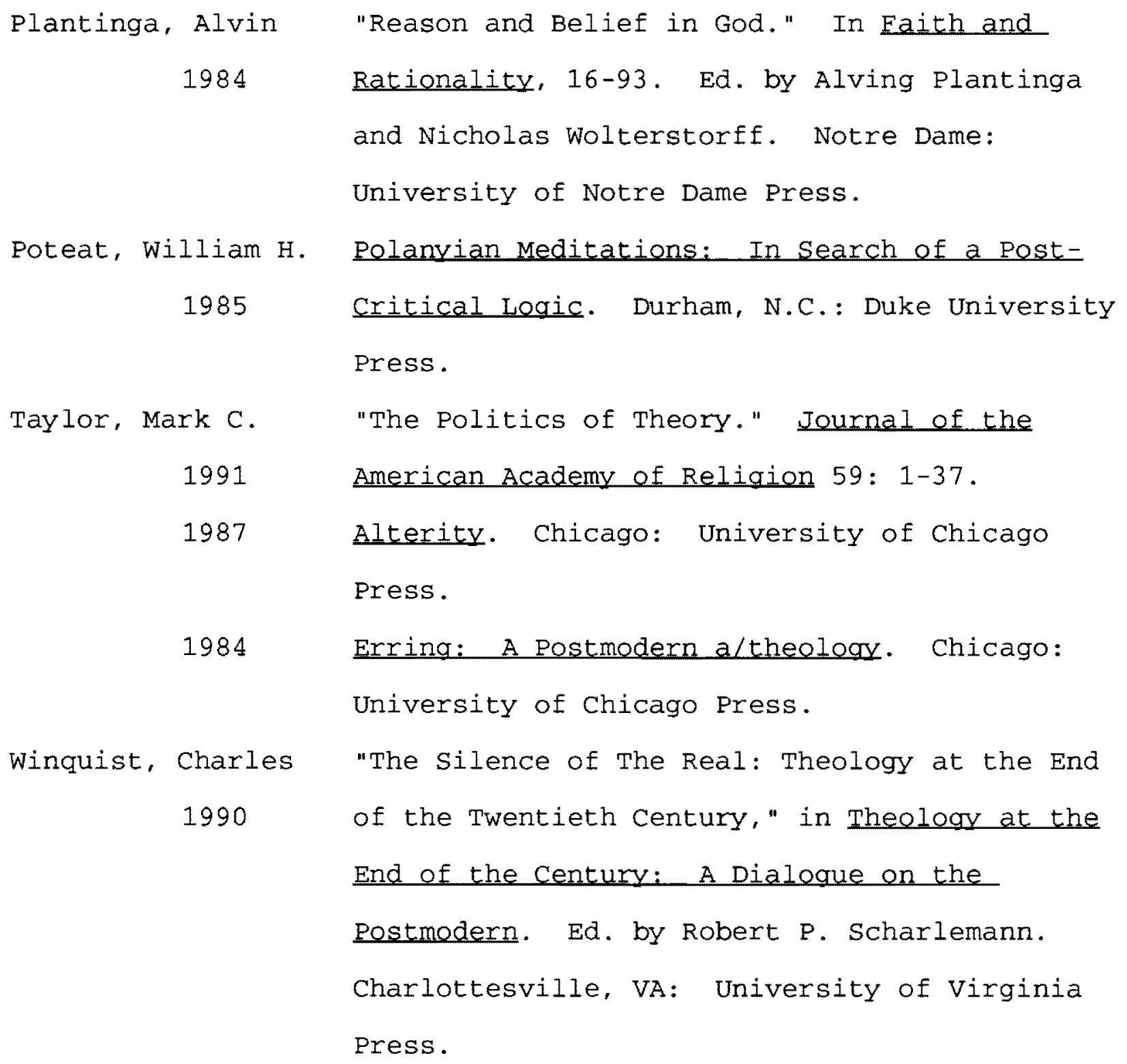

